\title{
O PROCESSO LEGISLATIVO COMO SALVAGUARDA DO DIREITO DE GREVE DO SERVIDOR PÚBLICO
}

\section{THE LEGISLATIVE PROCESS AS A SAFEGUARD OF THE PUBLIC SERVANT'S RIGHT TO GO ON STRIKE}

${ }^{1}$ Edilene Lôbo

\section{RESUMO}

O direito constitucional de greve só pode ser exercido mediante lei nacional específica sonegada há décadas. Reconhecida essa omissão haveria que se coarctá-la. Todavia, o Supremo Tribunal declarou a lacuna, mas criou regras e incidentes processuais por analogia, conferindo aos tribunais discricionariedade para impor regime "mais severo", atribuindo efeito erga omnes para substituir o legislador. O presente trabalho objetiva criticar a regulação desse direito por meio de decisão judicial afastada do devido processo legislativo. A metodologia utilizada, apoiada na teoria da separação dos poderes e da processualidade democrática, importou em exame da legislação, da jurisprudência e da literatura especializada.

Palavras-chave: Mandado de injunção, Processo legislativo, Greve, Servidor público

\begin{abstract}
The right to go on strike can only be realized after a specific national bill - such law has been denied for decades. Acknowledged the omission it should be remedied. The Supreme Court, nonetheless, declared the legislative gap but created, by analogy, rules and procedural issues, bestowing upon the remaining courts discretion to establish a stricter regime and erga omnes effect replacing the legislator. This work criticizes the right's regulation through judicial rulings removed from the legislative process. The methodology utilized, supported by Estate's functions separation and democratic process theories, consisted in exam of legislation, court rulings AND specialized literature.
\end{abstract}

Keywords: Brazilian writ of injunction, Legislative process, Strike, Public servant

\footnotetext{
${ }^{1}$ Doutora em Direito pela Pontifícia Universidade Católica de Minas Gerais - PUC/MG, Minas Gerais (Brasil). Professora da Graduação e do Mestrado em Direito da Universidade de Itaúna - UIT, Minas Gerais (Brasil). E-mail: edilenelobo@yahoo.com.br
} 


\section{INTRODUÇÃO}

Tratar de políticas públicas traz à mente as redes de proteção dos direitos sociais da comunidade, em que atores variados se articulam, mesclando ações públicas e privadas, focados na atenção ao destinatário desses esforços.

Os estudos desse assunto no processo coletivo têm dado importantes contribuições para a aplicação de teorias adequadas à sua construção, desenvolvimento e controle à luz do paradigma democrático.

O desafio, ao se superar o modelo absenteísta de Estado liberal e antidemocrático de Estado social, é examinar o tema sob as lentes da democracia participativa, transportando sua compreensão à elevação da autonomia do povo por meio de processos legítimos, inclusivos e libertários.

O discurso de aplicação desse modelo impõe que a democracia participativa seja a salvaguarda dos direitos sociais, num processo de retroalimentação constante, de modo a reconhecer seu caráter universal (BONAVIDES, 2008).

Por outro lado, desserve ao paradigma da inclusão e da valoração da autonomia do povo transferir o protagonismo da construção, desenvolvimento e controle das políticas públicas para o Judiciário, como se tem visto em fenômeno recente (GRINOVER e WATANABE, 2013; PENNA,

2011). Esse locus, ainda que coadjuvado por esses órgãos constitucionais, é do povo, sem qualquer deferência.

Políticas públicas legítimas, no espectro democrático, são aquelas construídas, reconstruídas e controladas pelos seus destinatários, ainda que com o auxílio dos agentes estatais, mas sempre por meio dos processos previstos na Constituição.

A propósito deles, os agentes estatais, especialmente os que compõem a categoria de servidores públicos, também são sujeitos de direitos sociais, dentre eles o de greve.

Diferente da ordem constitucional pretérita, que o proibia expressamente na Constituição de 1967, no artigo 157, $\S 7^{\circ}$ (BRASIL, 1967), repetido pela Emenda Constitucional de 1969, no artigo 162 (BRASIL, 1969), o direito de greve dos servidores públicos (excluídos os militares) está previsto na Constituição Federal de 1988, no artigo 37, inciso VII, a ser "exercido nos termos e limites definidos em lei específica” (BRASIL, 1988).

Estampado originariamente no texto de 1988, como dito, esse dispositivo só ganhou a redação atual com a Emenda Constitucional no 19/98 (BRASIL, 1998), e, até o momento, aguarda 
lei específica que o discipline ${ }^{1}$. Curiosamente, o direito de greve dos servidores públicos ainda não atingiu a estabilidade legislativa vista para os trabalhadores da iniciativa privada, estampada na Lei $n^{\text {o }} 7.783$ (BRASIL, 1989), passados mais de vinte e cinco anos da sua previsão constitucional.

A ausência de lei específica, por certo, lança esse direito fundamental no limbo do ordenamento jurídico, o que incursiona o legislador omisso em desacato aos comandos constitucionais e atrai possibilidade de correção forçada.

Como se aufere da própria Constituição, no inciso LXXI do artigo $5^{\circ}$ (BRASIL, 1988), a medida judicial adequada para a correção da lacuna que impeça a fruição de direitos fundamentais é o mandado de injunção, cuja modalidade coletiva tem apoio na jurisprudência e doutrina aplicáveis (PIOVESAN, 2003).

A par dessa ação típica para proteção judicial contra omissões legislativas, nesse quartil de século, a lacuna legislativa acerca do direito de greve foi tratada, inicialmente, como impossível de ser colmatada por atuação direta do Supremo Tribunal Federal, como se lê da decisão no Mandado de Injunção no 20, relatado pelo Ministro Celso de Mello, publicada no Diário do Judiciário em 22 de novembro de 1996:

A regra inscrita no art. 37, VII, da Carta Política - norma constitucional de eficácia limitada - constitui, pois, preceito de integração que reclama, em caráter necessário, para efeito de sua plena incidência, a mediação legislativa concretizadora do comando nela positivado.

O Congresso Nacional desempenha, nesse contexto, a relevantíssima função de sujeito concretizante da vontade formalmente proclamada no texto da Constituição. Sem que ocorra a interposição legislatoris, a norma constitucional de eficácia limitada não produzirá, em plenitude, as consequências jurídicas que lhe são pertinentes.

Ausente a lei complementar que constitui o requisito de incidência e de operatividade da norma positivada no art. 37, VII, do Texto Constitucional, não se revela possível e nem legítimo o exercício do direito subjetivo nela contemplado, o que autoriza o uso da via injuncional.

A imprescindibilidade da edição da lei complementar exigida pela norma constitucional em análise - essencial ao próprio exercício do direito de greve por ela outorgado em favor dos servidores públicos civis - tem sido reconhecida pelo magistério da doutrina, que assinala, ante a insuficiência dos elementos normativos que compõem a estrutura jurídica do preceito constitucional referido, a sua total inexequibilidade.

\footnotetext{
${ }^{1}$ Tramitam na Câmara dos Deputados, atualmente, dois projetos de lei que tentam disciplinar o assunto: o de $n^{\circ}$ 4532/2012 e o de $n^{\circ} 7205 / 2014$, o primeiro de autoria do Deputado Policarpo e o segundo de autoria do Deputado Assis de Melo.
} 
Entretanto, desde 2002, com o julgamento do Mandado de Injunção n ${ }^{\circ}$ 631, relatado pelo Ministro Ilmar Galvão, publicado no DJ de 02.08.2002, já se aventava a possibilidade que se materializou com o giro hermenêutico realizado pelo Supremo Tribunal Federal a partir do julgamento do Mandado de Injunção $n^{\circ} 670$ em outubro de 2007, publicado no

DJ-e de 31.10.2008².

Nesse leading case, o Supremo Tribunal Federal tomou para si o trabalho de resolver a lacuna que anteriormente reconhecia a cargo de complementação pelo Congresso Nacional, e o fez para estender à greve de servidores públicos as regras do setor privado, constantes da Lei $n^{\circ} 7.783$ (BRASIL, 1989).

Além disso, lançou mão da analogia para importar competência de órgãos judiciais para apreciação de conflitos referentes à greve de servidores, fixando a matéria processual do seguinte modo:

(...) se a paralisação for de âmbito nacional, ou abranger mais de uma região da justiça federal, ou ainda, compreender mais de uma unidade da federação, a competência para o dissídio de greve será do Superior Tribunal de Justiça (...). Ainda no âmbito federal, se a controvérsia estiver adstrita a uma única região da justiça federal, a competência serão dos Tribunais Regionais Federais (...). Para o caso da jurisdição no contexto estadual ou municipal, se a controvérsia estiver adstrita a uma unidade da federação, a competência será do respectivo Tribunal de Justiça (...). As greves de âmbito local ou municipal serão dirimidas pelo Tribunal de Justiça ou Tribunal Regional Federal com jurisdição sobre o local da paralisação, conforme se trate de greve de servidores municipais, estaduais ou federais. (BRASIL, 2008)

No que se refere às medidas cautelares incidentes, igualmente, previu que os tribunais mencionados serão competentes para apreciá-las, exemplificando possibilidade de aplicação.

Curioso é que o Mandado de Injunção no 670 (BRASIL, 2008), assim como os que lhe seguiram para formar o precedente ora examinado, foi proposto por sindicato de servidor civil, que buscava garantias para exercício do direito constitucional alentado, para vetar ordens judiciais que atentavam contra o movimento paredista.

\footnotetext{
${ }^{2}$ Seguiram-se a esse os Mandados de Injunção de $n^{\circ} 708$ e 712, inclusive, amplamente comentados no bojo desse Mandado de Injunção nº 670, todos os acórdão publicados no mesmo dia e julgados em concertação.
} 
A injunção foi deferida em parte pelo Relator originário, Ministro Maurício Corrêa, estabelecendo prazo para que o Congresso Nacional atuasse. Após vista do Ministro Gilmar Mendes, abriu-se a dissidência para formar a corrente majoritária, que se desprendeu do caso concreto ao tratar do que denominou de "imperativos de continuidade dos serviços públicos". Na sequência, se afiançou que o tribunal competente pode impor regime de greve mais severo que o da lei que entendeu aplicável, sob cogitações de "riscos decorrentes das possibilidades de que a regulação dos serviços públicos que tenham características afins a esses 'serviços ou atividades essenciais' seja menos severa que a disciplina dispensada aos serviços privados ditos essenciais".

Com isso, o Supremo Tribunal Federal não só declarou a lacuna legislativa e fixou prazos para sua correção, como criou regras e incidentes processuais por analogia, com base nas leis que menciona, ademais de conferir aos tribunais a discricionariedade de impor regime "mais severo" ao disposto na lei para esse direito, tratando do que não pleiteado pelos sindicatos impetrantes. Em arremate, conferiu à ordem o efeito erga omnes, substituindo o legislador para impor regra genérica, abstrata e impessoal, com violação da autonomia do Poder Legislativo e atropelo da finalidade constitucional do mandado de injunção.

Dessa forma, o que se tem no Brasil para regulação do direito de greve dos servidores públicos é arremedo de legislação que evidencia o protagonismo legislativo do Supremo Tribunal Federal, incompatível com o desenho constitucional para o desempenho da função legiferante e insuficiente para a proteção de direitos de tal jaez - já que operou para reduzi-lo.

O objetivo do presente trabalho, portanto, é criticar a regulação do direito de greve por meio de decisão judicial afastada do devido processo legislativo, diante da imposição do efeito erga omnes sem participação dos interessados diretos, a ponto de obrigar as Cortes de Justiça a fazê-lo de qualquer modo, como se tem de decisões recentes do Supremo Tribunal Federal, julgando reclamações variadas, comentadas adiante. Essa novidade, a propósito, confere atualidade ao presente trabalho, mesmo sete anos depois da prolação dos acórdãos nos Mandados de Injunção $n^{\circ}$ 670, 708 e 712 (BRASIL, 2008).

A importância do tema está no próprio status constitucional que lhe foi conferido pela Constituição de 1988, justificada pela constatação da má aplicação do instituto na praxis forense, com a postergação do acesso e desenvolvimento da greve como direito fundamental à igualdade e de resistência à violação da dignidade humana. A metodologia utilizada, apoiada na teoria da separação das funções estatais e da processualidade democrática, importou em 
exame da legislação, das decisões mencionadas e da literatura especializada, para se chegar às conclusões que o presente trabalho oferta.

\title{
2 GREVE TRADUZ DIREITO FUNDAMENTAL À IGUALDADE E À LIBERDADE
}

O direito de greve está assegurado no caput do artigo $9^{\circ}$ da Constituição brasileira desde sua redação original, "competindo aos trabalhadores decidir sobre a oportunidade de exercê-lo e sobre os interesses que devam por meio dele defender" (BRASIL, 1988).

Sua localização topográfica no texto constitucional - no meio dos direitos sociais, antes da regulação da nacionalidade, sucedendo direitos e deveres individuais e coletivos, encaixado no Título dos Direitos e Garantias Fundamentais - não deixa margem para outra conclusão senão a de que é essencial dignidade, liberdade e igualdade dos trabalhadores.

A Constituição de Portugal, por exemplo, em redação bastante aproximada à brasileira, no seu artigo $57^{\circ}$, o garante para os trabalhadores da iniciativa privada e proibe sua limitação por lei, que poderá, apenas, dispor sobre essencialidade e prestação mínima para atender necessidades sociais impreteríveis. Tal qual no modelo brasileiro, revela um direito fundamental, como esclarecem Canotilho e Vital Moreira (2007):

\begin{abstract}
A caracterização constitucional do direito à greve como um dos "direitos, liberdades e garantias" significa, entre outras coisas: (a) um direito subjetivo negativo, não podendo os trabalhadores ser proibidos ou impedidos de fazer greve, nem podendo ser compelidos a pôr termo a uma greve em curso (salvo se for ilícita); b) eficácia externa imediata, em relação a entidades privadas (art. $18^{\circ}-1$ ), não constituindo o exercício do direito de greve qualquer violação do contrato de trabalho, nem podendo as mesmas entidades neutralizar ou aniquilar praticamente esse direito; c) eficácia imediata, no sentido de directa aplicabilidade, não podendo o exercício deste direito depender da existência de qualquer lei concretizadora. (CANOTILHO e MOREIRA, 2007, p. 751)
\end{abstract}

O direito de greve permite exercício da dignidade humana, princípio fundamental da República, na medida em que se pode manejá-lo para resistir à exploração e à subjugação, na busca pela igualdade entre capital e trabalho. De novo, em termos de localização topográfica e de importância, se encontra acima dos valores sociais do trabalho e da livre iniciativa, eis que no inciso III do artigo $1^{\circ}$ da Constituição (BRASIL, 1988). Com efeito, também pode ser visto sob a perspectiva da igualdade:

Isso porque, até o desenvolvimento dos direitos sociais, vigoravam os direitos individuais e patrimoniais. No âmbito das relações de trabalho, as partes, no exercício de sua autonomia privada, estipulavam as formas de contratação. Mas a igualdade aqui era meramente formal e a empresa, sabidamente, detinha muito mais força e poder em relação ao trabalhador, individualmente considerado, o que acabava gerando sua superexposição, sob a chancela do Estado. 
Os obreiros perceberam que, sozinhos, sucumbiam frente ao capital, mas, juntos, ganhavam força e, assim, paulatinamente, foram se organizando, por meio dos sindicatos, e tentando alcançar um padrão de trabalho mais digno.

A igualdade entre as partes estava assim alcançada, pois, unidos via sindicato, os trabalhadores se tornam um ser coletivo, com a mesma força e poder que o da empresa, esta, ser coletivo por natureza. (MAGALHÃES; MIRANDA, 2012)

\subsection{O Mandado De Injunção Como Ação Coletiva De Defesa Do Direito De Greve}

Esse direito fundamental à dignidade, liberdade e igualdade, por força do inciso VII do artigo 37 da Constituição (BRASIL, 1988), como precitado, se estende aos servidores públicos civis e, nessa condição, é protegido da omissão por meio do mandado de injunção individual ou coletivo, como defende a doutrina aplicável (SILVA, 2008, p. 119 e ARAÚJO, 2011, p. 354).

\section{A FINALIDADE DO MANDADO DE INJUNÇÃO}

Posto na Constituição brasileira no rol de direitos fundamentais, na sua faceta de direito fundamental de acesso à jurisdição para efetividade da própria Constituição, o mandado de injunção veio para coarctar omissão legislativa que inviabilize direitos, liberdades constitucionais e prerrogativas da nacionalidade, soberania e cidadania.

Originário do sistema inglês, para exercício do juízo de equidade (equity) (SILVA, 2012, p. 168), sua finalidade é a de “(...) realizar concretamente em favor do impetrante o direito, liberdade ou prerrogativa sempre que a falta de norma regulamentadora torne inviável seu exercício.” (SILVA, 2012, p. 169).

Desse modo, José Afonso da Silva é enfático ao afirmar que mandado de injunção não visa obturar lacuna legislativa com efeito erga omnes, como se fosse alternativa subsidiária da ação de inconstitucionalidade por omissão (SILVA, 2012, p. 169).

Essa posição, que ressalta o conteúdo da decisão no mandado de injunção plasmado na "outorga direta do direito reclamado" (SILVA, 2012, p. 170), é corroborada por Flávia Piovesan (2003):

(...) o mandado de injunção tem como principal finalidade conferir imediata viabilidade ao exercício de direitos, liberdades e prerrogativas constitucionais, obstado em virtude da ausência de regulamentação.

Revela-se o mandado de injunção como verdadeiro instrumento de realização do princípio da aplicabilidade imediata das normas definidoras dos direitos e garantias fundamentais. (PIOVESAN, 2003, p. 141-142)

Nessa linha de raciocínio, adotar o mandado de injunção para proteger a liberdade associativa de determinado grupo de servidores, como fizeram as entidades sindicais 
que manejaram os Mandados de Injunção $n^{\circ}$ 670, 708 e 712 (BRASIL, 2008) perante o Supremo Tribunal Federal, encontra pleno respaldo na Constituição.

Diferente disso é lançar mão da mesma ação constitucional em desfavor do direito fundamental e, à guisa de dar-lhe aplicabilidade, invadir a esfera legislativa federal para criar regras processuais aleatórias.

Cobra relevo, com igual vigor pela falta de explicação plausível, o fato de o Supremo Tribunal Federal não ter compartilhado de sua decisão nos Mandados de Injunção referidos com os interessados diretos, o que bem poderia fazê-lo com o uso do instituto do amicus curiae, avultando exercício egoístico do poder, alheio à democracia participativa.

Não se duvida mais, com apoio na teoria procedimentalista do discurso (HABERMAS, 2003), que é corolário lógico do paradigma democrático que os destinatários das normas sejam seus coautores, conferindo legitimidade ao ordenamento jurídico por meio do processo enquanto garantia de argumentação, independente do órgão que o utilize: o judiciário, no caso concreto, ou o legislativo, na construção original das leis gerais, abstratas e impessoais, pela espécie que lhe compete.

Essa revisão do processo legislativo pelo Supremo Tribunal Federal, por meio de mandados de injunção, às avessas do paradigma em tela, não atende à legitimação dessa jurisdição constitucional. É o que se apreende a partir dos ensinamentos de Bruno Cláudio Penna Amorim Pereira:

O Tribunal Constitucional institucionaliza-se como o instrumento de consolidação da democracia e da política deliberativa, na medida em que se consubstancia como o canal entre a vontade popular e a atividade legislativa, buscando conjugar e compatibilizar a as esferas pública e privada, interligando-as em prol da formação de um espaço público democrático. A partir de tal compreensão procedimentalista do Direito, no contexto do paradigma do Estado Democrático de Direito, o princípio da separação dos poderes estará verdadeiramente consagrado e a legitimidade da jurisdição constitucional do processo legislativo plenamente assegurada. (PEREIRA, 2012, p. 156)

\section{O LIMITE DO SUPREMO TRIBUNAL FEDERAL NO DESEMPENHO DO MISTER INJUNCIONAL}

Como descrito no inciso LXXI do artigo $5^{\circ}$ da Constituição (BRASIL, 1988), o mandado de injunção atende aos reclamos do impetrante, resolvendo-se a controvérsia entre as partes demandantes até mesmo por imperativos do princípio da inércia da jurisdição, que impede decisões que se estendam além do pedido. Esse comando veda impregnações inautênticas e individuais do intérprete sem provocação do destinatário, sob o risco de suceder a inefetividade do direito fundamental pretendido, como se viu com o direito de greve que, 
dado com uma mão - ao se prever uma legislação temporária para lhe regular -, foi tirado com a outra, ao se estabelecer maior rigor na apreciação dos casos concretos, juízo a ser exercido de modo livre e sem as amarras de lei pelos tribunais.

MARRAFON (2015), tratando da vinculação do intérprete ao texto constitucional, ressalta “(...) que a observância do texto, sem peripécias interpretativas, é fundamental para preservar a lei e salvá-la do império das vontades, pois o Judiciário (e, em especial, seu órgão de cúpula) não pode desempenhar o papel do novo soberano.”

De modo inverso ao recomendado, desgarrado do texto constitucional, o protagonismo legislativo do Supremo Tribunal Federal ante o direito em questão gerou efeito cascata, se irradiando para os tribunais brasileiros.

Demonstrativo dessa extensão legislativa é o Regimento Interno do Tribunal de Justiça de Minas Gerais (MINAS GERAIS, 2015), que se compôs dos artigos 362 a 368, tratando de ações coletivas relacionadas ao direito de greve. Nessa mesma esteira, o Regimento Interno do Tribunal de Justiça de São Paulo (SÃO PAULO, 2015), cujos artigos 239 a 246 tratam do "Dissídio Coletivo por Greve". Lacônico, mas não silente, o Regimento Interno do Tribunal de Justiça do Rio de Janeiro (RIO DE JANEIRO, 2013), no artigo $3^{\circ}$, dispõe sobre a competência do Órgão Especial para julgar "medidas judiciais que venham a ser requeridas em virtude de estado de greve deflagrado por servidores estaduais e municipais".

Esses dispositivos regimentais ${ }^{3}$ disciplinam atos processuais, com a fixação de prazos para o manejo de recursos e oferta de contestação, alheios à competência privativa da União para legislar sobre tal matéria, conforme inciso I do artigo 22 da Constituição Federal (BRASIL, 1988).

Por outro lado, é bem verdade que há vários julgados do Supremo Tribunal Federal impondo aos Tribunais de Justiça a obrigatoriedade de julgar conflitos grevistas mesmo sem regras expressas, como se pode ver das seguintes Reclamações: $\mathrm{n}^{\circ} 10.580$ (BRASIL, 2010) Relator Ministro Ayres Britto; $\mathrm{n}^{\circ} 13.218$ (BRASIL, 2012), Relatora Ministra Cármen Lúcia; nº 18.370 (BRASIL, 2014), Relator Ministro Gilmar Mendes; nº 18.203 (BRASIL, 2014), Relator Ministro Luiz Fux; nº 18.122 (BRASIL, 2014), Relator Ministro Ricardo Lewandowski; no 21.153 (BRASIL, 2015), Relatora Ministra Rosa Weber; e $\mathrm{n}^{\mathrm{o}} 21.8442$ (BRASIL, 2015), de relatoria do Ministro Roberto Barroso (para ficar só nessas).

\footnotetext{
${ }^{3}$ Tomando esses três tribunais como referência apena pela densidade populacional.
} 
Nesse contexto, considerando que em todas as reclamações mencionadas prevaleceu decisão proferida por um único Ministro, louvando a possibilidade de que o conteúdo dos referidos Regimentos Internos pudesse ser convalidado por essas ordens do Supremo Tribunal Federal ou por meio de lei estadual, ainda assim não se afigura validade constitucional, porque regras processuais são exigentes de lei específica a cargo do Legislativo Federal.

Sendo assim, ainda que se possa discutir a possibilidade de que regras procedimentais, distinguindo-as daquelas processuais, sejam passíveis de produção pelos Estados Federados, os Tribunais de Justiça, por evidente, com eles não se confundem. Daí que, sob nenhum ângulo se encontra argumentos para defesa das regras processuais dispondo sobre ações tangendo direito de greve de servidores públicos, como as inseridas em regimentos de tribunais ou convalidadas por decisão liminar do Supremo Tribunal Federal.

É certo que o processo legislativo constitucional encontra guarida na Constituição a partir do artigo 60, se estendendo por toda a Seção VIII do Capítulo I, que disciplina a distribuição da função legiferante ao Congresso Nacional, composto pela Câmara dos Deputados e pelo Senado Federal. As matérias que devem ser tratadas no plano nacional, igualmente, se encontram dispostas dos artigos 20 ao 32 do mesmo diploma, não restando margem para qualquer dúvida acerca da autonomia conferida a essa representação do poder popular.

Assim, qualquer atuação dos outros órgãos estatais que modifique esse desenho institucional incorre em inconstitucionalidade por usurpação de função alheia.

Por isso que o próprio Supremo Tribunal Federal vem censurando medidas que invadam essa seara, como ele próprio fez, por exemplo, ao julgar lei paulista que disciplinava atos do juiz para processamento das ações regidas pela Lei 9.099/1995. Veja-se o voto do Ministro Eros Grau na ADI 2257, publicado no DJ de 26.8.2005, que discorre sobre matéria "eminentemente processual, a propósito da qual a legislação estadual não pode dispor, visto que aos Estados- membros é facultado legislar, concorrentemente, apenas sobre procedimentos". Ao invocar Francesco Carnellutti, consigna:

Nos dizeres de Carnelutti, procedimento "é uma sucessão de atos não só finalmente mas também causalmente vinculados, porquanto cada um deles supõe o precedente e assim o último supõe o grupo todo", distinguindo-se de processo, que é "o conjunto de todos os atos necessários em cada caso para a composição da lide". (BRASIL 2005) 
Em trilha idêntica, no julgamento da ADI 3041, relatada pelo Ministro Ricardo Lewandowski, decisão publicada no DJ de 01.12.2012, o Supremo Tribunal Federal reafirmou a invasão legislativa em hipóteses que tais, apoiado na doutrina de CINTRA, GRINOVER e DINAMARCO (2005):

\begin{abstract}
A doutrina costuma distinguir três classes de normas processuais, a saber: (i) normas de organização judiciária, que tratam principalmente da estrutura dos órgãos judiciários e seus auxiliares; (ii) - normas processuais em sentido estrito, que cuidam do processo como tal e atribuem poderes e deveres processuais; e (iii) - normas procedimentais, que se referem ao modus procedendi, ou seja, à estrutura e coordenação dos atos que compõem o processo. Muito embora atualmente se cogite de um conceito "moderno" de processo, de natureza complexa, que abarcaria tanto o procedimento quanto a relação jurídica processual, o certo é que tal dicotomia já se encontra incorporada à Constituição. Com efeito, a partir dela delimita-se a competência privativa da União para legislar sobre direito processual, (art. 22, I), e, de um lado, de outro, a competência concorrente dos Estados para dispor acerca de matéria procedimental (art. 24, XI). (BRASIL, 2012)
\end{abstract}

Antes tais considerações, a posição adotada é de verdadeiro anacronismo porque, corretamente, não permite validade a leis estaduais que tratem de regras processuais, por invasão legislativa, mas impõe aos tribunais que julguem ações envolvendo greve de servidores, constituindo suas próprias regras processuais a forceps, em subordinação do direito constitucional de modo vexatório.

Essa contradição dá a nota da inadequação das decisões nos mandados de injunção estudados neste trabalho, que acabou por gerar mais problemas práticos na aplicabilidade de seus comandos genéricos e aleatórios, do que se reservasse a cada caso concreto o exame das possibilidades apresentadas pelos impetrantes, com seleção dos argumentos apresentados a partir da hermenêutica, na busca da concreção do direito de greve para permitir eficácia ao texto constitucional que o criou.

\title{
CONCLUSÕES
}

O mandado de injunção, ação constitucional que possibilita a colmatação de lacunas no ordenamento jurídico, lapsos que impeçam o exercício das liberdades fundamentais, não é apanágio para obturar o locus de criação do direito pelo devido processo legislativo. É que, conforme HABERMAS (1997), somente "as condições processuais da gênese democrática das leis" pode impor legitimidade ao Direito.

Dessa forma, até que se conclua o processo legislativo criador da lei para exercício do direito de greve dos servidores públicos, não se lhe pode impor mais restrições do que 
aquelas existentes na lei aplicável à iniciativa privada, somente se admitindo restrições e/ou processamentos específicos, a partir de cada caso concreto julgado.

A salvaguarda do direito de greve, essencial à dignidade, liberdade e igualdade dos trabalhadores públicos e privados, se dará por meio da construção de leis que contem com ampla participação dos interessados, desde sindicatos, organizações variadas da sociedade civil, trabalhadores públicos e privados, até qualquer cidadão que se interesse pelo assunto.

O simulacro que se converteu a extensão da lei de greve dos trabalhadores privados para os servidores públicos, por meio de decisão judicial, não resiste à exigência de legitimidade que o paradigma democrático impõe ao desempenho das funções estatais.

\section{REFERÊNCIAS}

ARAÚJO, Florivaldo Dutra de. Negociação Coletiva dos Servidores Públicos. Belo Horizonte: Editora Fórum, 2011.

BONAVIDES, Paulo. Teoria constitucional da democracia participativa. $3^{\mathrm{a}}$ ed. São Paulo: Malheiros Editores, 2008.

BRASIL. Constituição (1988). Constituição da República Federativa do Brasil. Brasília, DF: Senado Federal, $\quad 1988 . \quad$ Disponível em:

<http://www.planalto.gov.br/ccivil_03/Constituicao/Constituicao.htm>. Acesso em: 16 dez. 2015.

BRASIL. Constituição (1967). Constituição da República Federativa do Brasil. Brasilia, DF: Senado $\quad$ Federal, $1967 . \quad$ Disponível em:

<http://www.planalto.gov.br/ccivil_03/Constituicao/Constituicao67.htm>. Acesso em 18 dez. 2015.

BRASIL. Emenda à Constituição (1969). Constituição da República Federativa do Brasil. Brasilia, DF: Outorgada pela Junta Militar. Disponível em:

<http://www.planalto.gov.br/ccivil_03/Constituicao/Emendas/Emc_anterior1988/e mc01-69.htm\#art2>. Acesso em 18 dez. 2015.

BRASIL. Emenda à Constituição n o 19, de 04 de junho de 1998. Constituição da República Federativa do Brasil. Brasília, DF: Senado Federal, 1988. Disponível em: http://www.planalto.gov.br/ccivil_03/Constituicao/Emendas/Emc/emc19.htm>. Acesso em: 18 dez. 2015.

BRASIL. Lei $\mathrm{n}^{\circ}$ 7.783, de 28 de junho de 1989. Dispõe sobre o exercício do direito de greve e dá outras providências. Diário Oficial da União. Brasilia, DF, 29 jun. 1989. Disponível em:

<http://www.planalto.gov.br/ccivil_03/Leis/L7783.htm>. Acesso em $18 \mathrm{dez} 2015$. 
BRASIL. Supremo Tribunal Federal. Mandado de Injunção no 20/DF. Relator: Ministro Celso de Mello. Data da publicação: 22 dez. 1996. Disponível em < http://redir.stf.jus.br/paginadorpub/paginador.jsp?docTP=AC\&docID=81733>. Acesso em 18 dez. 2015.

BRASIL. Supremo Tribunal Federal. Mandado de Injunção $n^{\circ}$ 661/MS. Relator: Ministro Ilmar

Galvão. Data da publicação: 02 ago. 2002. Disponível em

<http://redir.stf.jus.br/paginadorpub/paginador.jsp?docTP=AC\&docID=81883>. Acesso em 18 dez. 2015.

BRASIL. Supremo Tribunal Federal. Mandado de Injunção n ${ }^{\circ}$ 670/ES. Relator Originário: Ministro Maurício Corrêa. Relator para o Acórdão Ministro Gilmar Mendes. Data da publicação: 31 out. 2008.

em

$<$ http://redir.stf.jus.br/paginadorpub/paginador.jsp?docTP=AC\&docID=558549>.

Acesso em 18 dez. 2015.

BRASIL. Supremo Tribunal Federal. Mandado de Injunção n ${ }^{\circ}$ 708/DF. Relator: Ministro $\begin{array}{llllll}\text { Gilmar Mendes. } & \text { Data da publicação: } & 31 & \text { out. } & 2008 .\end{array}$ Disponível em $<$ http://redir.stf.jus.br/paginadorpub/paginador.jsp?docTP=AC\&docID=558551 $>$. Acesso em 18 dez. 2015.

BRASIL. Supremo Tribunal Federal. Mandado de Injunção n ${ }^{\circ}$ 712/PA. Relator: Ministro Eros Grau. Data da publicação: 31 out. 2008. Disponível em < http://redir.stf.jus.br/paginadorpub/paginador.jsp?docTP=AC\&docID=558553>. Acesso em 18 dez. 2015.

BRASIL. Supremo Tribunal Federal. Reclamação no 10.580/DF. Relator: Ministro Ayres $\begin{array}{lllll}\text { Britto. Data da } & \text { publicação: } & 21 & \text { out. }\end{array}$ Disponível em: <http://www.stf.jus.br/portal/jurisprudencia/listarJurisprudencia.asp?s1=\%28Rc1\%24\%2ESC $\mathrm{LA} \% 2 \mathrm{E}+\mathrm{E}+10580 \% 2 \mathrm{ENUME} \% 2 \mathrm{E} \% 29+\mathrm{NAO}+\mathrm{S} \% 2 \mathrm{EPRES} \% 2 \mathrm{E} \&$ base=baseMonocraticas $\&$ url=http://tin yurl.com/bedy794>. Acesso em: 18 dez. 2015.

BRASIL. Supremo Tribunal Federal. Reclamação nº 13.218/SC. Relatora: Ministra Cármen $\begin{array}{lllll}\text { Lúcia. Data da } & \text { publicação: } & 25 & \text { abr. } & 2012 .\end{array}$ Disponível em: <http://www.stf.jus.br/portal/processo/verProcessoAndamento.asp?incidente $=4192288>$. Acesso em: 18 dez. 2015.

BRASIL. Supremo Tribunal Federal. Reclamação ${ }^{\circ}$ 18.370/SC. Relator: Ministro Gilmar $\begin{array}{lllll}\text { Mendes. Data } & \text { da } & \text { publicação: } & 10 & \text { out. }\end{array}$ Disponível em: 
$<$ http://www.stf.jus.br/portal/jurisprudencia/listarJurisprudencia.asp?s1=\%28Rcl\%24\%2ESC $\mathrm{LA} \% 2 \mathrm{E}+\mathrm{E}+18370 \% 2 \mathrm{ENUME} \% 2 \mathrm{E} \% 29+\mathrm{NAO}+\mathrm{S} \% 2 \mathrm{EPRES} \% 2 \mathrm{E} \&$ base=baseMonocraticas \& url=http://tin yurl.com/me3rn2v >. Acesso em: 18 dez. 2015.

BRASIL. Supremo Tribunal Federal. Reclamação no 18.203/DF. Relator: Ministro Luiz Fux.

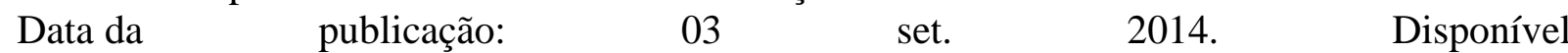
em: $<$ http://www.stf.jus.br/portal/jurisprudencia/listarJurisprudencia.asp?s1=\%28Rcl\%24\%2E SCLA \%2E+E+18203\%2ENUME\%2E\%29+NAO+S\%2EPRES\%2E\&base=baseMonocraticas \&url=http://tin yurl.com/n96rhyn>. Acesso em: 18 dez. 2015.

BRASIL. Supremo Tribunal Federal. Reclamação $\mathrm{n}^{\circ}$ 18.122/SC. Relator: Ministro Ricardo Lewandowski. Data da publicação: 08 ago. 2014. Disponível em: <http://www.stf.jus.br/portal/jurisprudencia/listarJurisprudencia.asp?s1=\%28Rc1\%24\%2ESC $\mathrm{LA} \% 2 \mathrm{E}+\mathrm{E}+18122 \% 2 \mathrm{ENUME} \% 2 \mathrm{E} \% 29+\mathrm{NAO}+\mathrm{S} \% 2 \mathrm{EPRES} \% 2 \mathrm{E} \&$ base=baseMonocraticas \& url=http://tin yurl.com/ltsfxqj>. Acesso em: 18 dez. 2015.

BRASIL. Supremo Tribunal Federal. Reclamação no 21.153/PA. Relatora: Ministra Rosa Weber. Data da publicação: 04 ago. 2015. Disponível em: < http://www.stf.jus.br/portal/jurisprudencia/listarJurisprudencia.asp?s1=\%28Rc1\%24\%2ESCLA $\% 2 \mathrm{E}+\mathrm{E}+21153 \% 2 \mathrm{ENUME} \% 2 \mathrm{E} \% 29+\mathrm{NAO}+\mathrm{S} \% 2 \mathrm{EPRES} \% 2 \mathrm{E} \&$ base=baseMonocraticas\&url= http://tiny url.com/ohe88vr>. Acesso em: 18 dez. 2015.

BRASIL. Supremo Tribunal Federal. Reclamação no 21.842/RS. Relator: Ministro Roberto $\begin{array}{lllll}\text { Barroso. Data } & \text { da } & \text { publicação: } & 19 & \text { out. }\end{array}$ Disponível em:

<http://www.stf.jus.br/portal/jurisprudencia/listarJurisprudencia.asp?s1=\%28Rc1\%24\%2ESC $\mathrm{LA} \% 2 \mathrm{E}+\mathrm{E}+21842 \% 2 \mathrm{ENUME} \% 2 \mathrm{E} \% 29+\mathrm{NAO}+\mathrm{S} \% 2 \mathrm{EPRES} \% 2 \mathrm{E} \&$ base=baseMonocraticas \& url=http://tin yurl.com/ngcbcla>. Acesso em: 18 dez. 2015.

BRASIL. Supremo Tribunal Federal. Ação Direta de Inconstitucionalidade $n^{0}$ 1919/SP. Relator: Ministra Ellen Gracie. Data da publicação: 01 ago. 2003. Disponível em: < http://redir.stf.jus.br/paginadorpub/paginador.jsp?docTP=AC\&docID=266800> . Acesso em 18 dez.2015.

BRASIL. Supremo Tribunal Federal. Ação Direta de Inconstitucionalidade $n^{0}$ 2257/SP. Relator: Ministro Eros Grau. Data da publicação: 26 ago. 2005. Disponível em: < http://redir.stf.jus.br/paginadorpub/paginador.jsp?docTP=AC\&docID=375362> . Acesso em 18 dez. 2015.

BRASIL. Supremo Tribunal Federal. Ação Direta de Inconstitucionalidade $n^{\circ}$ 3041/RS. Relator: Ministro Ricardo Lewandowski. Data da publicação: 01 fev. 2012. Disponível em: < http://redir.stf.jus.br/paginadorpub/paginador.jsp?docTP=TP\&docID=1672851> . Acesso em 18 dez. 2015.

CANOTILHO, J.J. Gomes; e MOREIRA, Vilta. Constituição da República Portuguesa anotada. Vol. I. $1^{\text {a }}$ ed. brasileira, $4^{\mathrm{a}}$ ed. portuguesa revista. Coimbra e São Paulo: Editora Revista dos Tribunais, 2007. 
DIAS, Ronaldo Brêtas de Carvalho; SOARES, Carlos Henrique (Coord.). Técnica Processual. Belo Horizonte: Editora Del Rey, 2013.

CINTRA, Antonio Carlos de Araújo; GRINOVER, Ada Pellegrini; DINAMARCO, Cândido Rangel. Teoria Geral do Processo. 21 ${ }^{\mathrm{a}}$ ed. São Paulo: Malheiros Editores, 2005.

GRINOVER, Ada Pellegrini; e WATANABE, Kazuo. O controle jurisdicional de políticas públicas. $2^{\mathrm{a}}$ ed. Rio de Janeiro: Forense, 2013.

HABERMAS, HABERMAS, Jurgen, 1929 - Direito e democracia: entre a facticidade e validade. Tradução Flávio Beno Siebeneichler. 2ed. Rio de Janeiro: Tempo Brasileiro, v. 1 e 2, 2003.

LEAL, Rosemiro. Processo como teoria da lei democrática. Belo Horizonte: Editora Forum, 2010.

MAGALHÃES, Aline Carneiro; e MIRANDA, Lúlian. A greve como direito fundamental: características e perspectivas trabalhista-administrativas. Revista do Tribunal Regional do Trabalho da $3^{\text {a }}$ Região. Belo Horizonte, v. 56, no 86, jul./dez. 2012, p. 53-76.

MARQUES, Frederico. Dos Regimentos Internos dos Tribunais In: Nove Ensaios Jurídicos em Homenagem ao Centenário do Tribunal de Justiça de São Paulo. Lex Editora, 1975

Organização Judiciária e Processo In Revista de Direito Processual Civil, vol. I, São Paulo: Saraiva, 1960.

MARRAFON, Marcos. Texto constitucional não é norma mas vincula. Disponível em:< http://www.conjur.com.br/2015-dez-28/constituicao-poder-texto-constitucional-naonorma- vincula>.Acesso: 28 dez. 2015.

MINAS GERAIS. Regimento Interno do Tribunal de Justiça de Minas Gerais. Resolução do Tribunal Pleno $\mathrm{n}^{\circ}$ 03, de 26 de julho de 2012, atualizada em agosto de 2015. Disponível em: <http://www.tjmg.jus.br/portal/legislacao/regimento-interno/>. Acesso em 08 de dez de 2015.

PENNA, Saulo Versiani. Controle e implementação processual de políticas públicas no Brasil. Belo Horizonte: Editora Fórum, 2011.

PEREIRA, Bruno Cláudio Penna Amorim. Jurisdição constitucional do processo legislativo. Legitimidade, Reinterpretação e Remodelagem do Sistema no Brasil. Belo Horizonte: Editora Fórum, 2012.

PIOVESAN, Flávia. Proteção judicial contra omissões legislativas. $2^{a}$ ed. São Paulo: RT, 2003. 
RIO DE JANEIRO. Regimento Interno do Tribunal de Justiça do Rio de Janeiro. Atualizado em $10 \quad$ set. 2013. Disponível em: http://portaltj.tjrj.jus.br/c/document_library/get_file?uuid=5031dbf8-af75-4cff-b2110fef7e97774f\&groupId=10136>. Acesso em: 18 dez. 2015.

SÃO PAUlO. Regimento Interno do Tribunal de Justiça de São Paulo. Compilação aprovada em sessão do Órgão Especial. Diário do Judiciário do Estado. São Paulo, SP, 24 out. 2013, alterado em 03 nov. 2015.

SILVA, Antônio Álvares. Greve no serviço público depois da decisão do STF. São Paulo: LTR, 2008.

SILVA, José Afonso da. Comentário contextual à Constituição. $8^{\mathrm{a}}$ ed. São Paulo: Malheiro Editores, 2012.

STRECK, Lênio Luiz. Hermenêutica, Constituição e Processo, ou de "como discricionariedade não combina com democracia: o contraponto da resposta correta". In MACHADO, Felipe Daniel Amorim; CATTONI DE OLIVEIRA, Marcelo Andrade (coord.). Constituição e Processo: a contribuição do processo ao constitucionalismo brasileiro. Belo Horizonte: Del Rey, 2009. 